\title{
Point Mutation Analysis of PMP22 in Patients Referred for Hereditary Neuropathy with Liability to Pressure Palsies
}

\author{
Samuel B. Brown', David J. Bunyan'1,2 \\ ${ }^{1}$ Wessex Regional Genetics Laboratory, Salisbury District Hospital, Salisbury, UK \\ ${ }^{2}$ Human Genetics Division, Southampton University School of Medicine, Southampton, UK \\ Email: Dave.Bunyan@salisbury.nhs.uk
}

Received 18 August 2014; revised 10 September 2014; accepted 8 October 2014

Copyright (C) 2014 by authors and Scientific Research Publishing Inc.

This work is licensed under the Creative Commons Attribution International License (CC BY). http://creativecommons.org/licenses/by/4.0/ C) (i) Open Access

\begin{abstract}
A cohort of 404 patients referred for hereditary neuropathy with liability to pressure palsies was tested initially for the common PMP22 whole gene deletion. 94 whole gene deletions were detected, plus three partial gene deletions, and the remaining 307 patients were screened for $P M P 22$ point mutations. Nine point mutations were identified ( $8.5 \%$ of all mutations), eight of which were in exon 5, suggesting a point mutation hotspot for individuals with this condition. Sequencing analysis of PMP22 exon 5 should therefore be included as a routine diagnostic test for gene deletion-negative patients.
\end{abstract}

\section{Keywords}

Point Mutations, PMP22, HNPP

\section{Introduction}

Hereditary neuropathy with liability to pressure palsies (HNPP) was first described in 1947 [1]. Patients present with transient episodes of weakness and or sensory loss that can present in any limb and sometimes also in the auditory nerve. Motor nerve conduction velocities can be normal or nearly normal with focal areas of slowing at the wrist, around the elbow or knee or distally in the peroneal nerve [2] [3]. Other symptoms can include nerve palsies of the ulna, pes cavus, scoliosis, deafness and carpal tunnel syndrome, but due to the episodic nature and transient clinical manifestations, HNPP may often go undiagnosed [4]-[6]. 
Autosomal dominant inheritance of HNPP was first shown in 1954 [4], and the relevant gene was finally identified when two groups showed that a deletion of the entire PMP22 gene resulted in the condition [7] [8], due to unequal crossing over between homologous low copy repeats on chromosomes 17 [9]. Although a PMP22 whole gene deletion was shown to be the major cause of HNPP [10]-[13], the first point mutation within $P M P 22$ was reported in a family with classic HNPP symptoms a few years later [14]. The PMP22 gene encodes a 22-kD protein, named peripheral myelin protein 22, that comprises around $5 \%$ of peripheral nervous system myelin. It is produced primarily by Schwann cells and expressed in the compact portion of all myelinated fibers in the peripheral nervous system [15].

As PMP22 is the only gene that has been linked to HNPP, point mutation analysis of this gene in patients without a known whole or partial gene deletion is therefore likely to reveal additional mutations as mutations that reduce the functional level of PMP22 can cause a HNPP phenotype [16]. However, since the first reported PMP22 point mutation, very few others have been published. There are only 20 HNPP-causing mutations currently listed on the molgen and HGMD databases (www.molgen.ua.ac.be, www.hgmd.cf.ac.uk) and only a few more present in the literature (see Table 1). Almost all of these mutations are from individual reports of a single mutation, so it is difficult to get an idea of the point mutation frequency or gene distribution in HNPP referrals. To this end, we have analysed a cohort of over 400 patients referred with a potential diagnosis of HNPP. Deletions were initially detected using the multiplex ligation-dependent probe amplification (MLPA) technique [42], and the deletion-negative patients were screened for point mutations in the four coding exons of PMP22 in order to determine the pick-up rate and distribution of such mutations amongst HNPP referrals.

\section{Materials and Methods}

\subsection{Test Populations}

Between 1991 and 2014, a cohort of 404 independently-ascertained patients was collected at our laboratory following referrals from centres within the catchment area of the Wessex Regional Genetics Laboratory. As this is a laboratory-based study, we have no access to clinical data, nor do we have details of the referral criteria used by the clinicians.

This study falls in the realm of routine clinical care and consent for diagnostic testing was obtained from all patients as part of the referral process.

\subsection{MLPA Analysis}

MLPA was carried out according to the manufacturer's instructions with the current CMT probe mix at the time of referral (MRC-Holland, The Netherlands) either kit P033 or kit P405. Any patients referred prior to 2002 were retroactively tested with the P033 kit. MLPA PCR products $(0.5 \mu \mathrm{l})$ were added to $0.2 \mu \mathrm{l}$ of Genescan $^{\mathrm{TM}}-500 \mathrm{ROX}^{\mathrm{TM}}$ Size Standard (Applied Biosystems, USA) and $9 \mu \mathrm{l}$ of Hi-Di Formamide (Applied Biosystems, USA) and separated on an ABI 3130xl Genetic Analyzer (Applied Biosystems, USA) using a $36 \mathrm{~cm}$ array and 3130 POP-7TM array polymer (Applied Biosystems, USA). The run conditions were as follows: injection voltage $=1.2 \mathrm{kVolts}$, injection time $=5$ seconds, oven temperature $=60^{\circ} \mathrm{C}$, run voltage $=15 \mathrm{kVolts}$, run time $=$ 20 minutes. Subsequent data was analysed using the MLPA analysis function of the Gene Marker (version 1.85) software (SoftGenetics, USA).

\subsection{PMP22 Sequencing Analysis}

Mutation analysis of the four coding exons of the PMP22 gene (exons 2-5 Ensembl transcript ENST00000395938, gene ENSG00000109099) was carried out by direct sequencing analysis. PCR products were first generated using a standard PCR reaction with a $25 \mu \mathrm{l}$ volume and a $60^{\circ} \mathrm{C}$ annealing temperature using the relevant exon primers; 2F-ctcctcgcaggcagaaact, 2R-ctgaaccagcaggagcacg, 3F-tccccttttcttcactcct, 3R-ccaataagcgtttccagctc, 4F-catggccagctctcctaac, 4R-actaatcattccgcagacttg, 5F-ccgctctgccatggactc and 5R-ttccctatgtacgctcagag. These products were then sequenced using the standard protocol of the Big-Dye ${ }^{\circledR}$ Terminator v1.1 Cycle Sequencing Kit (Applied Biosystems, USA) and separated on an ABI 3130xl Genetic Analyzer (Applied Biosystems, USA). Subsequent data was analysed using the Mutation Surveyor (version 3.1) software (SoftGenetics, USA).

Any missense mutations were assessed using the Alamut mutation interpretation software (version 1.5- 
Table 1. A summary of HNPP-causing PMP22 mutations.

\begin{tabular}{|c|c|c|c|c|}
\hline Location & Base change & Protein change & Mutation & Reference \\
\hline Exon 2 & c.11delT & p.(Leu4fs) & Frameshift & [17] \\
\hline Exon 2 & c.19_20delAG & p.(Leu7fs) & Frameshift & [18] \\
\hline Exon 2 & c.31_39delCTCCACGTC & p.(Leu11fs) & Frameshift & [19] \\
\hline Exon 2 & c. $65 \mathrm{C}>\mathrm{T}$ & p.(Ser22Phe) & Missense & [14] \\
\hline Intron 2 & c. $78+1 \mathrm{G}>\mathrm{T}$ & & Splicing & [20] \\
\hline Intron 2 & c. $78+5 \mathrm{G}>\mathrm{A}$ & & Splicing & [21] \\
\hline Intron 2 & c.79-13T $>$ A & ? p.(Gln27fs) & Splicing/Frameshift & This study \\
\hline Exon 3 & c. $88 \mathrm{G}>\mathrm{A}$ & p.(Val30Met) & Missense & [22] \\
\hline Intron 3 & c. $178+1 \mathrm{G}>\mathrm{C}$ & & Splicing & [23] \\
\hline Intron 3 & c. $179-1 \mathrm{G}>\mathrm{C}$ & & Splicing & [24] \\
\hline Exon 4 & c. $183 \mathrm{G}>\mathrm{A}$ & p.(Trp61Ter) & Termination & [25] \\
\hline Exon 4 & c. $183 \mathrm{G}>\mathrm{A}$ & p.(Trp61Ter) & Termination & [26] \\
\hline Exon 4 & c. $199 \mathrm{G}>\mathrm{A}$ & p.(Ala67Thr) & Missense & [27] \\
\hline Exon 4 & c.227delG & p.(Ser76fs) & Frameshift & [28] \\
\hline Exon 4 & c.281_282insG & p.(Gly94fs) & Frameshift & [29] \\
\hline Exon 4 & c.281_282insG & p.(Gly94fs) & Frameshift & [30] \\
\hline Exon 4 & c.289delT & p.(Tyr97fs) & Frameshift & [31] \\
\hline Exon 4 & c.297delT & p.(Gly100fs) & Frameshift & [32] \\
\hline Intron 4 & c. $320-1 \mathrm{G}>\mathrm{C}$ & & Splicing & [21] \\
\hline $\begin{array}{c}\text { Intron 4/ } \\
\text { Exon } 5\end{array}$ & c.320-1_320delGGinsTA & & Splicing & This study \\
\hline Exon 5 & c.320G $>\mathrm{T}$ & p.(Gly107Val) & Missense & [33] \\
\hline Exon 5 & c. $328 \mathrm{G}>\mathrm{A}$ & p.(Val110Met) & Missense & This study \\
\hline Exon 5 & c. $353 \mathrm{C}>\mathrm{T}$ & p.(Thr118Met) & Missense & [34] \\
\hline Exon 5 & c. $353 \mathrm{C}>\mathrm{T}$ & p.(Thr118Met) & Missense & [35] \\
\hline Exon 5 & c.353C $>\mathrm{T}$ & p.(Thr118Met) & Missense & This study \\
\hline Exon 5 & c. $353 \mathrm{C}>\mathrm{T}$ & p.(Thr118Met) & Missense & This study \\
\hline Exon 5 & c.364_365delCC & p.(Pro122fs) & Frameshift & [36] \\
\hline Exon 5 & c. $372 \mathrm{G}>\mathrm{A}$ & p.(Trp124Ter) & Termination & [37] \\
\hline Exon 5 & c. $372 \mathrm{G}>\mathrm{A}$ & p.(Trp124Ter) & Termination & [38] \\
\hline Exon 5 & c. $392 \mathrm{C}>\mathrm{G}$ & p.(Ser131Cys) & Missense & This study \\
\hline Exon 5 & c. $395 \mathrm{~A}>\mathrm{G}$ & p.(Tyr132Cys) & Missense & This study \\
\hline Exon 5 & c. $419 \mathrm{G}>\mathrm{A}$ & p.(Trp140Ter) & Termination & [21] \\
\hline Exon 5 & c.433_434insC & p.(Leu145fs) & Frameshift & [39] \\
\hline Exon 5 & c.434delT & p.(Leu145fs) & Frameshift & This study \\
\hline Exon 5 & c.434delT & p.(Leu145fs) & Frameshift & [40] \\
\hline Exon 5 & c. $469 \mathrm{C}>\mathrm{T}$ & p.(Arg157Trp) & Missense & This study \\
\hline Exon 5 & c. $475 \mathrm{C}>\mathrm{T}$ & p.(Arg159Cys) & Missense & [41] \\
\hline
\end{tabular}

Interactive Biosoftware, France). Alamut uses the programs SIFT (sift.jcvi.org) and Polyphen (genetics. bwh. harvard.edu/pph2/) to predict causality. SIFT predicts whether an amino acid substitution in a protein will have a phenotypic effect, based on the degree of conservation of amino acid residues in sequence alignments derived from closely related sequences, collected through PSI-BLAST (blast.ncbi.nlm.nih.gov/Blast.cgi). The amino acid substitution is given a score from 0 to 1 and is predicted to be damaging if the score is $\leq 0.05$, and tolerated 
if the score is $>0.05$ [43]. Polyphen classifies amino acid substitutions as "benign", "possibly damaging", or "probably damaging" based on data compiled from all damaging alleles with known effects on the molecular function causing human Mendelian diseases present in the UniProtKB database (uniprot.org), together with common human non-synonymous single nucleotide polymorphisms without annotated involvement in disease [44].

Potential splice site mutations were analysed using the Fruitfly splice predictor program within Alamut (http://www.fruitfly.org/seq tools/splice.html).

\section{Results}

\subsection{MLPA Analysis}

Dosage analysis of the PMP22 gene showed that 94 of the 404 referrals had the standard whole gene deletion, while three had a partial gene deletion - the first had a deletion of exons 1-3, the second had a deletion of exons 4 and 5 and the third had a deletion of exons 2 and 3 . The remaining 307 patients were screened for point mutations within PMP22.

\subsection{PMP22 Sequencing Analysis}

A single sequence change was found in nine of the 307 patients (see Table 2). All mutation nomenclature is based on Ensembl transcript ID ENST00000395938 where base 1 is the first base of the translation initiation codon. Eight of these changes were within exon 5 of PMP22 with one destroying the exon 5 splice acceptor site and one frameshift mutation. The remaining six caused an amino acid substitution, and Alamut mutation interpretation software predicts that all six are likely to be pathogenic. The ninth change was in intron 2 where the substitution c.79-13T>A was predicted by the Fruitfly splice predictor program to create a new splice site at position c.79-25_-24 which has a higher likelihood of usage than the original one at c.79-2_-1. This would result in a 23 base pair insertion if the alternative splice site is used (c.78_79insGATATCTATCTGATTCTCTCTAG).

\section{Discussion}

This study confirms that deletions are the most common HNPP-causing mutation but also demonstrates that point mutation analysis extends the diagnostic yield for HNPP referrals. Nine sequence changes were detected in patients referred with a diagnosis of HNPP. The nine changes comprised of eight different mutations, so no point mutation founder effect was evident. Two of these mutations (c.353C $>\mathrm{T}$ p.(Thr118Met) and c.469C $>\mathrm{T}$ p.(Arg157Trp)) are listed as deleterious by Clin Var (ncbi.nlm.nih.gov/clinvar/), UniProt (uniprot.org) and dbSNP (ncbi.nlm.nih.gov/SNP/) while the other six were novel and unclassified. The p.(Thr118Met) mutation was originally published in the literature as a possible polymorphism [45], but subsequent studies showed that it did cause HNPP [34] [35], and although heterozygosity for p.(Arg157Trp) had not been reported as causing HNPP, it had been shown to cause Dejerine-Sottas disease in homozygous form [46]. In silico analysis suggests

Table 2. The in silico predictions of the nine PMP22 sequence changes found in the study.

\begin{tabular}{|c|c|c|c|c|c|}
\hline Patient & Location & Base change & Protein change & Polyphen prediction & SIFT prediction \\
\hline 1 & Intron 2 & c.79-13T $>$ A & Potential frameshift (c.78_79ins23) & Not applicable & Not applicable \\
\hline 2 & Exon 5 & c.320-1_320delGGinsTA & $\begin{array}{c}\text { Destruction of normal exon 4/exon } 5 \\
\text { splicing }\end{array}$ & Not applicable & Not applicable \\
\hline 3 & Exon 5 & c.328G $>$ A & p.(Val110Met) & Probably damaging & Deleterious \\
\hline 4 & Exon 5 & c. $353 \mathrm{C}>\mathrm{T}$ & p.(Thr118Met) & Probably damaging & Deleterious \\
\hline 5 & Exon 5 & c. $353 \mathrm{C}>\mathrm{T}$ & p.(Thr118Met) & Probably damaging & Deleterious \\
\hline 6 & Exon 5 & c. $392 \mathrm{C}>\mathrm{G}$ & p.(Ser131Cys) & Possibly damaging & Deleterious \\
\hline 7 & Exon 5 & c. $395 \mathrm{~A}>\mathrm{G}$ & p.(Tyr132Cys) & Possibly damaging & Deleterious \\
\hline 8 & Exon 5 & c.434delT & Frameshift & Not applicable & Not applicable \\
\hline 9 & Exon 5 & c. $469 \mathrm{C}>\mathrm{T}$ & p.(Arg157Trp) & Probably damaging & Deleterious \\
\hline
\end{tabular}


causality (loss of PMP22 function) for the three unclassified amino acid substitutions (c.328G >A p.(Val110Met), c.392C $>$ G p.(Ser131Cys) and c.395A $>$ G p.(Tyr132Cys)), while the c.320-1_320delGGinsTA (destruction of splice site) and c.434delT (protein reading frame shift) mutations are clearly deleterious. The remaining base change, c.79-13T $>\mathrm{A}$, is potentially deleterious based on the in silico data, but RNA analysis would be required to prove causality, and at present we have been unable to obtain an RNA sample from this patient.

The interesting finding from this study is the distribution of the point mutations, with eight out of nine changes clustering within a single coding exon, namely exon 5 . There is a paucity of reported PMP22 mutations in the literature, but our results are supported by the Inherited Peripheral Neuropathies Mutation Database (IPNMD; molgen.vib-ua.be) and a literature search which garnered 28 other HNPP-causing PMP22 mutations (see Table 1), eleven of which are in exon five. Combining the mutation database figures with those from our study, a total of 51\% of all point mutations (19 out of 37), and 77\% of amino acid substitutions (10 out of 13), are within the last coding exon of $P M P 22$.

Mutations in PMP22 can also cause Charcot-Marie-Tooth type 1A (CMT1A) [47] but, in contrast to HNPP, the IPNMD shows a clustering of PMP22 point mutations in CMT1A referrals within exon 4 of the gene (28 out of 40; 70\%). It seems clear from this that genotype-phenotype correlations exist in PMP22, with the development of HNPP or CMT1A symptoms dependant upon the location of the point mutation. Exons 4 and 5 each account for approximately one-third of the coding sequence of PMP22, so a slight increase in mutations identified in these exons would be expected, but the distribution frequencies in CMT1A referrals (exon $4 ; \chi^{2}=12.8, \mathrm{p}<$ 0.01 ) and HNPP referrals (exon $5 ; \chi^{2}=6.0, \mathrm{p}<0.01$ ) are clearly skewed. PMP22 has four transmembrane domains involving amino acid numbers 5-26, 65-84, 96-117 and 137-156 [48]. Of the ten different amino acid substitutions listed in Table 1, six of these lie adjacent to these transmembrane domains at positions 30, 118, 131, 132, 157 and 159, while four are within the transmembrane regions at positions 22, 67, 107 and 110, so presumably these amino acid substitutions cause a HNPP phenotype by disrupting the transmembrane domains.

The majority of mutation positive cases from our cohort $(n=94)$ had the standard whole gene deletion, while three had a partial gene deletion. These 97 deletion cases were all detected by MLPA analysis, but the identification of nine point mutations, accounting for $8.5 \%$ of all positive cases, highlighted the importance of PMP22 sequence analysis in patients with HNPP. As eight of the nine mutations were within exon 5 of the gene (as are $\sim 51 \%$ of all reported HNPP-causing point mutations), we would recommend that, as a minimum, sequencing of this exon is performed on all HNPP gene deletion-negative cases.

\section{References}

[1] De Jong, J.G.Y. (1947) Over families met hereditarie disposite tot het optreten van neuritiden, gecorreleard met migraine. Psychiatrische en Neurologische Bladenuitgegeven, 50, 60-76.

[2] Lewis, R.A., Sumner, A.J. and Shy, M.E. (2000) Electrophysiological Features of Inherited Demyelinating Neuropathies: A Reappraisal in the Era of Molecular Diagnosis. Muscle and Nerve, 23, 1472-1487. http://dx.doi.org/10.1002/1097-4598(200010)23:10<1472::AID-MUS3>3.0.CO;2-\#

[3] Li, J., Krajewski, K., Shy, M.E. and Lewis, R.A. (2002) Hereditary Neuropathy with Liability to Pressure Palsy: The Electrophysiology Fits the Name. Neurology, 58, 1769-1773. http://dx.doi.org/10.1212/WNL.58.12.1769

[4] Davies, D.M. (1954) Recurrent Peripheral-Nerve Palsies in a Family. The Lancet, 254, 266-268. http://dx.doi.org/10.1016/S0140-6736(54)90193-2

[5] Gabreels-Festen, A.A.W.M., Gabreels, F.J.M., Joosten, E.M.G., Vingerhoets, H.M. and Renier, W.O. (1992) Hereditary Neuropathy with Liability to Pressure Palsies in Childhood. Neuropediatrics, 23, 138-143. http://dx.doi.org/10.1055/s-2008-1071329

[6] Potocki, L., Chen, K.S., Koeuth, T., Killian, J., Iannaccone, S.T., Shapira, S.K., et al. (1999) DNA Rearrangements on Both Homologues of Chromosome 17 in a Mildly Delayed Individual with a Family History of Autosomal Dominant Carpal Tunnel Syndrome. American Journal of Human Genetics, 64, 471-478. http://dx.doi.org/10.1086/302240

[7] Chance, P.F., Alderson, M.K., Leppig, K.A., Lensch, M.W., Matsunami, N., Smith, B., et al. (1993) DNA Deletion Associated with Hereditary Neuropathy with Liability to Pressure Palsies. Cell, 72, 143-151. http://dx.doi.org/10.1016/0092-8674(93)90058-X

[8] Mariman, E.C.M., Gabreels-Festen, A.A.W.M., van Beersum, S.E.C., Valentijn, L.J., Baas, F., Bolhuis, P.A., et al. (1993) Gene for Hereditary Neuropathy with Liability to Pressure Palsies (HNPP) Maps to Chromosome 17 at or Close to the Locus for HMSN Type 1. Human Genetics, 92, 87-90. http://dx.doi.org/10.1007/BF00216152

[9] Le Guern, E., Sturtz, F., Gugenheim, M., Gouider, R., Bonnebouche, C., Ravise, N., et al. (1994) Detection of Deletion 
within 17p11.2 in 7 French Families with Hereditary Neuropathy with Liability to Pressure Palsies (HNPP). Cytogenetics and Cell Genetics, 65, 261-264. http://dx.doi.org/10.1159/000133643

[10] Mariman, E.C.M., Gabreels-Festen, A.A.W.M., van Beersum, S.E.C., Valentijn, L.J., Baas, F., Bolhuis, P.A., et al. (1994) Prevalence of the 1.5-Mb 17p Deletion in Families with Hereditary Neuropathy with Liability to Pressure Palsies. Annals of Neurology, 36, 650-655. http://dx.doi.org/10.1002/ana.410360415

[11] Silander, K., Halonen, P., Sara, R., Kalimo, H., Falck, B., Savontaus, M.L. (1994) DNA Analysis in Finnish Patients with Hereditary Neuropathy with Liability to Pressure Palsies (HNPP). Journal of Neurology, Neurosurgery and Psychiatry, 57, 1260-1262. http://dx.doi.org/10.1136/jnnp.57.10.1260

[12] Umehara, F., Kiwaki, T., Yoshikawa, H., Nishimura, T., Nakagawa, M., Matsumoto, W., et al. (1995) Deletion in Chromosome 17p11.2 including the Peripheral Myelin Protein-22 (PMP-22) Gene in Hereditary Neuropathy with Liability to Pressure Palsies. Journal of Neurological Sciences, 133, 173-176. http://dx.doi.org/10.1016/0022-510X(95)00188-8

[13] Gonnaud, P.M., Sturtz, F., Fourbil, Y., Bonnebouche, C., Tranchant, C., Warter, J.M., et al. (1995) DNA Analysis as a Tool to Confirm the Diagnosis of Asymptomatic Hereditary Neuropathy with Liability to Pressure Palsies (HNPP) with Further Evidence for the Occurrence of de Novo Mutations. Acta Neurologica Scandinavica, 92, 313-318. http://dx.doi.org/10.1111/j.1600-0404.1995.tb00135.x

[14] Kleopa, K.A., Georgiou, D.M., Nicolaou, P., Koutsou, P., Papathanasiou, E., Kyriakides, T., et al. (2004) A Novel PMP22 Mutation ser22phe in a Family with Hereditary Neuropathy with Liability to Pressure Palsies and CMT1A Phenotypes. Neurogenetics, 5, 171-175. http://dx.doi.org/10.1007/s10048-004-0184-1

[15] Snipes, G.J., Suter, U., Welcher, A.A. and Shooter, E.M. (1992) Characterization of a Novel Peripheral Nervous System Myelin Protein (PMP-22/SR13). Journal of Cell Biology, 117, 225-238. http://dx.doi.org/10.1083/jcb.117.1.225

[16] Li, J., Ghandour, K., Radovanovic, D., Shy, R.R., Krajewski, K.M., Shy, M.E., et al. (2007) Stoichiometric Alteration of PMP22 Protein Determines the Phenotype of Hereditary Neuropathy with Liability to Pressure Palsies. Archives of Neurology, 64, 974-978. http://dx.doi.org/10.1001/archneur.64.7.974

[17] Muglia, M., Patitucci, A., Rizzi, R., Ungaro, C., Conforti, F.L., Gabriele, A.L., et al. (2007) A Novel Point Mutation in PMP22 Gene in an Italian Family with Hereditary Neuropathy with Liability to Pressure Palsies. Journal of Neurological Sciences, 263, 194-197. http://dx.doi.org/10.1016/j.jns.2007.05.034

[18] Nicholson, G.A., Valentijn, L.J., Cherryson, A.K., Kennerson, M.L., Bragg, T.L., DeKroon, R.M., et al. (1994) A Frame Shift Mutation in the PMP22 Gene in Hereditary Neuropathy with Liability to Pressure Palsies. Nature Genetics, 6, 263-266. http://dx.doi.org/10.1038/ng0394-263

[19] Zhang, F., Khajavi, M., Connolly, A.M., Towne, C.F., Batish, S.D. and Lupski, J.R. (2009) The DNA Replication FoSTeS/MMBIR Mechanism Can Generate Genomic, Genic and Exonic Complex Rearrangements in Humans. Nature Genetics, 41, 849-853. http://dx.doi.org/10.1038/ng.399

[20] Bort, S., Nelis, E., Timmerman, V., Sevilla, T., Cruz-Martinez, A., Martinez, F., et al. (1997) Mutational Analysis of the MPZ, PMP22 and Cx32 Genes in Patients of Spanish Ancestry with Charcot-Marie-Tooth Disease and Hereditary Neuropathy with Liability to Pressure Palsies. Human Genetics, 99, 746-754. http://dx.doi.org/10.1007/s004390050442

[21] Brožková, D., Mazanec, R., Rychlý, Z., Haberlová, J., Böhm, J., Staněk, J., et al. (2011) Four Novel Point Mutations in the PMP22 Gene with Phenotypes of HNPP and Dejerine-Sottas Neuropathy. Muscle and Nerve, 44, 819-822. http://dx.doi.org/10.1002/mus.22189

[22] Sahenk, Z., Chen, L. and Freimer, M. (1998) A Novel PMP22 Point Mutation Causing HNPP Phenotype: Studies on Nerve Xenografts. Neurology, 5, 702-707. http://dx.doi.org/10.1212/WNL.51.3.702

[23] Bellone, E., Balestra, P., Ribizzi, G., Schenone, A., Zocchi, G., Di Maria, E., et al. (2006) An Abnormal mRNA Produced by a Novel PMP22 Splice Site Mutation Associated with HNPP. Journal of Neurology, Neurosurgery and Psychiatry, 77, 538-540. http://dx.doi.org/10.1136/jnnp.2005.075242

[24] Meuleman, J., Pou-Serradell, A., Lofgren, A., Ceuterick, C., Martin, J.J., Timmerman, V., et al. (2001) A Novel 3’Splice Site Mutation in Peripheral Myelin Protein 22 Causing Hereditary Neuropathy with Liability to Pressure Palsies. Neuromuscular Disorders, 11, 400-403. http://dx.doi.org/10.1016/S0960-8966(00)00214-5

[25] Haites, N.E., Nelis, E. and Van Broeckhoven, C. (1998) 3rd Workshop of the European CMT Consortium: 54th ENMC International Workshop on Genotype/Phenotype Correlations in Charcot-Marie-Tooth Type 1 and Hereditary Neuropathy with Liability to Pressure Palsies, 28-30 November 1997, Naarden, The Netherlands. Neuromuscular Disorders, 8, 591-603. http://dx.doi.org/10.1016/S0960-8966(98)00067-4

[26] Nelis, E., Haites, N. and Van Broeckhoven, C. (1999) Mutations in the Peripheral Myelin Genes and Associated Genes in Inherited Peripheral Neuropathies. Human Mutation, 13, 11-28. http://dx.doi.org/10.1002/(SICI)1098-1004(1999)13:1<11::AID-HUMU2>3.0.CO;2-A

[27] Nodera, H., Nishimura, M., Logigian, E.L., Herrmann, D.N. and Kaji, R. (2003) HNPP Due to a Novel Missense Mu- 
tation of the PMP22 Gene. Neurology, 60, 1863-1864. http://dx.doi.org/10.1212/01.WNL.0000066049.13848.F2

[28] Luigetti, M., Conte, A., Madia, F., Mereu, M.L., Zollino, M., Marangi, G., et al. (2008) A New Single-Nucleotide Deletion of PMP22 in an HNPP Family without Recurrent Palsies. Muscle and Nerve, 38, 1060-1064. http://dx.doi.org/10.1002/mus.21083

[29] Young, P., Wiebusch, H., Stogbauer, F., Ringelstein, B., Assmann, G. and Funke, H. (1997) A Novel Frameshift Mutation in PMP22 Accounts for Hereditary Neuropathy with Liability to Pressure Palsies. Neurology, 48, 450-452. http://dx.doi.org/10.1212/WNL.48.2.450

[30] Lenssen, P.P., Gabreëls-Festen, A.A., Valentijn, L.J., Jongen, P.J., van Beersum, S.E., van Engelen, B.G., et al. (1998) Hereditary Neuropathy with Liability to Pressure Palsies. Phenotypic Differences between Patients with the Common Deletion and a PMP22 Frame Shift Mutation. Brain, 121, 1451-1458. http://dx.doi.org/10.1093/brain/121.8.1451

[31] Yurrebaso, I., Casado, O.L., Barcena, J., de Nanclares, G.P. and Aguirre, U. (2014) Clinical, Electrophysiological and Magnetic Resonance Findings in a Family with Hereditary Neuropathy with Liability to Pressure Palsies Caused by a Novel PMP22 Mutation. Neuromuscular Disorders, 24, 56-62. http://dx.doi.org/10.1016/j.nmd.2013.09.005

[32] Moszyńska, I., Kabzińska, D., Sinkiewicz-Darol, E. and Kochański, A. (2009) A Newly Identified Thr99fsX110 Mutation in the PMP22 Gene Associated with an Atypical Phenotype of the Hereditary Neuropathy with Liability to Pressure Palsies. Acta Biochimica Polonica, 56, 627-630.

[33] Marrosu, M.G., Vaccargiu, S., Marrosu, G., Vannelli, A., Cianchetti, C. and Muntoni, F. (1997) A Novel Point Mutation in the Peripheral Myelin Protein 22 (PMP22) Gene Associated with Charcot-Marie-Tooth Disease Type 1A. Neurology, 48, 489-493. http://dx.doi.org/10.1212/WNL.48.2.489

[34] Russo, M., Laurá, M., Polke, J.M., Davis, M.B., Blake, J., Brandner, S., et al. (2011) Variable Phenotypes Are Associated with PMP22 Missense Mutations. Neuromuscular Disorders, 21, 106-114. http://dx.doi.org/10.1016/j.nmd.2010.11.011

[35] Shy, M.E., Scavina, M.T., Clark, A., Krajewski, K.M., Li, J., Kamholz, J., et al. (2006) T118M PMP22 Mutation Causes Partial Loss of Function and HNPP-Like Neuropathy. Annals of Neurology, 59, 358-364. http://dx.doi.org/10.1002/ana.20777

[36] Bissar-Tadmouri, N., Parman, Y., Boutrand, L., Deymeer, F., Serdaroglu, P., Vandenberghe, A., et al. (2000) Mutational Analysis and Genotype/Phenotype Correlation in Turkish Charcot-Marie-Tooth Type 1 and HNPP Patients. Clinical Genetics, 58, 396-402. http://dx.doi.org/10.1034/j.1399-0004.2000.580511.x

[37] Pareyson, D. and Taroni, F. (1996) Deletion of the PMP22 Gene and Hereditary Neuropathy with Liability to Pressure Palsies. Current Opinions in Neurology, 9, 348-354. http://dx.doi.org/10.1097/00019052-199610000-00006

[38] Pegoraro, E., Gavassini, B.F., Benedetti, S., Menditto, I., Zara, G., Padoan, R., et al. (2005) Co-Segregation of LMNA and PMP22 Gene Mutations in the Same Family. Neuromuscular Disorders, 15, 858-862. http://dx.doi.org/10.1016/j.nmd.2005.08.008

[39] Zéphir, H., Stojkovic, T., Latour, P., Hurtevent, J.F., Blankaert, F. and Vermersch P. (2005) A Family with a Novel Frameshift Mutation in the PMP22 Gene (c.433_434insC) Causing a Phenotype of Hereditary Neuropathy with Liability to Pressure Palsies. Neuromuscular Disorders, 15, 493-497. http://dx.doi.org/10.1016/j.nmd.2005.04.007

[40] Taroni, F., Botti, S., Sghirlanzoni, A., Botteon, G., DiDonato, S. and Pareyson, D. (1995) A Nonsense Mutation in the PMP22 Gene in Hereditary Neuropathy with Liability to Pressure Palsies (HNPP) Not Associated with the 17p11.2 Deletion. American Journal of Human Genetics, 57, A229.

[41] Gess, B., Jeibmann, A., Schirmacher, A., Kleffner, I., Schilling, M. and Young, P. (2011) Report of a Novel Mutation in the PMP22 Gene Causing an Axonal Neuropathy. Muscle and Nerve, 43, 605-609. http://dx.doi.org/10.1002/mus.21973

[42] Schouten, J.P., McElgunn, C.J., Waaijer, R., Zwijnenburg, D., Diepvens, F. and Pals, G. (2002) Relative Quantification of 40 Nucleic Acid Sequences by Multiplex Ligation-Dependent Probe Amplification. Nucleic Acids Research, 30, e57. http://dx.doi.org/10.1093/nar/gnf056

[43] Ng, P.C. and Henikoff, S. (2001) Predicting Deleterious Amino Acid Substitutions. Genome Research, 11, $863-874$. http://dx.doi.org/10.1101/gr.176601

[44] Adzhubei, I.A., Schmidt, S., Peshkin, L., Ramensky, V.E., Gerasimova, A., Bork, P., et al. (2010) A Method and Server for Predicting Damaging Missense Mutations. Nature Methods, 7, 248-249. http://dx.doi.org/10.1038/nmeth0410-248

[45] Young, P., Stögbauer, F., Eller, B., de Jonghe, P., Löfgren, A., Timmerman, V., et al. (2000) PMP22 Thr118Met Is Not a Clinically Relevant CMT1 Marker. Journal of Neurology, 247, 696-700. http://dx.doi.org/10.1007/s004150070113

[46] Parman, Y., Plante-Bordeneuve, V., Guiochon-Mantel, A., Eraksoy, M. and Said, G. (1999) Recessive Inheritance of a New Point Mutation of the PMP22 Gene in Dejerine-Sottas Disease. Annals of Neurology, 45, 518-522. 
http://dx.doi.org/10.1002/1531-8249(199904)45:4<518::AID-ANA15>3.0.CO;2-U

[47] Nelis, E., De Jonghe, P., De Vriendt, E., Patel, P.I., Martin, J.J. and Van Broeckhoven, C. (1998) Mutation Analysis of the Nerve Specific Promoter of the Peripheral Myelin Protein 22 Gene in CMT1 Disease and HNPP. Journal of Medical Genetics, 35, 590-593. http://dx.doi.org/10.1136/jmg.35.7.590

[48] Sakakura, M., Hadziselimovic, A., Wang, Z., Schey, K.L. and Sanders, C.R. (2011) Structural Basis for the Trembler-J Phenotype of Charcot-Marie-Tooth Disease. Structure, 19, 1160-1169. http://dx.doi.org/10.1016/j.str.2011.05.009 
Scientific Research Publishing (SCIRP) is one of the largest Open Access journal publishers. It is currently publishing more than 200 open access, online, peer-reviewed journals covering a wide range of academic disciplines. SCIRP serves the worldwide academic communities and contributes to the progress and application of science with its publication.

Other selected journals from SCIRP are listed as below. Submit your manuscript to us via either submit@scirp.org or Online Submission Portal.
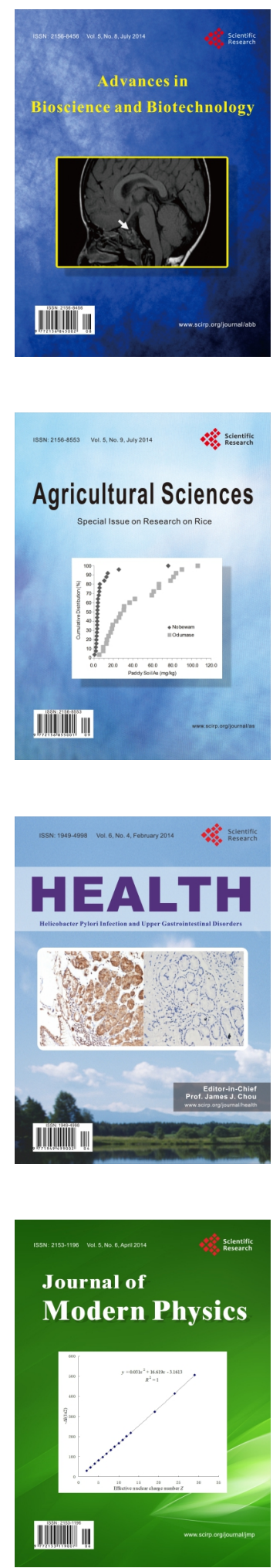
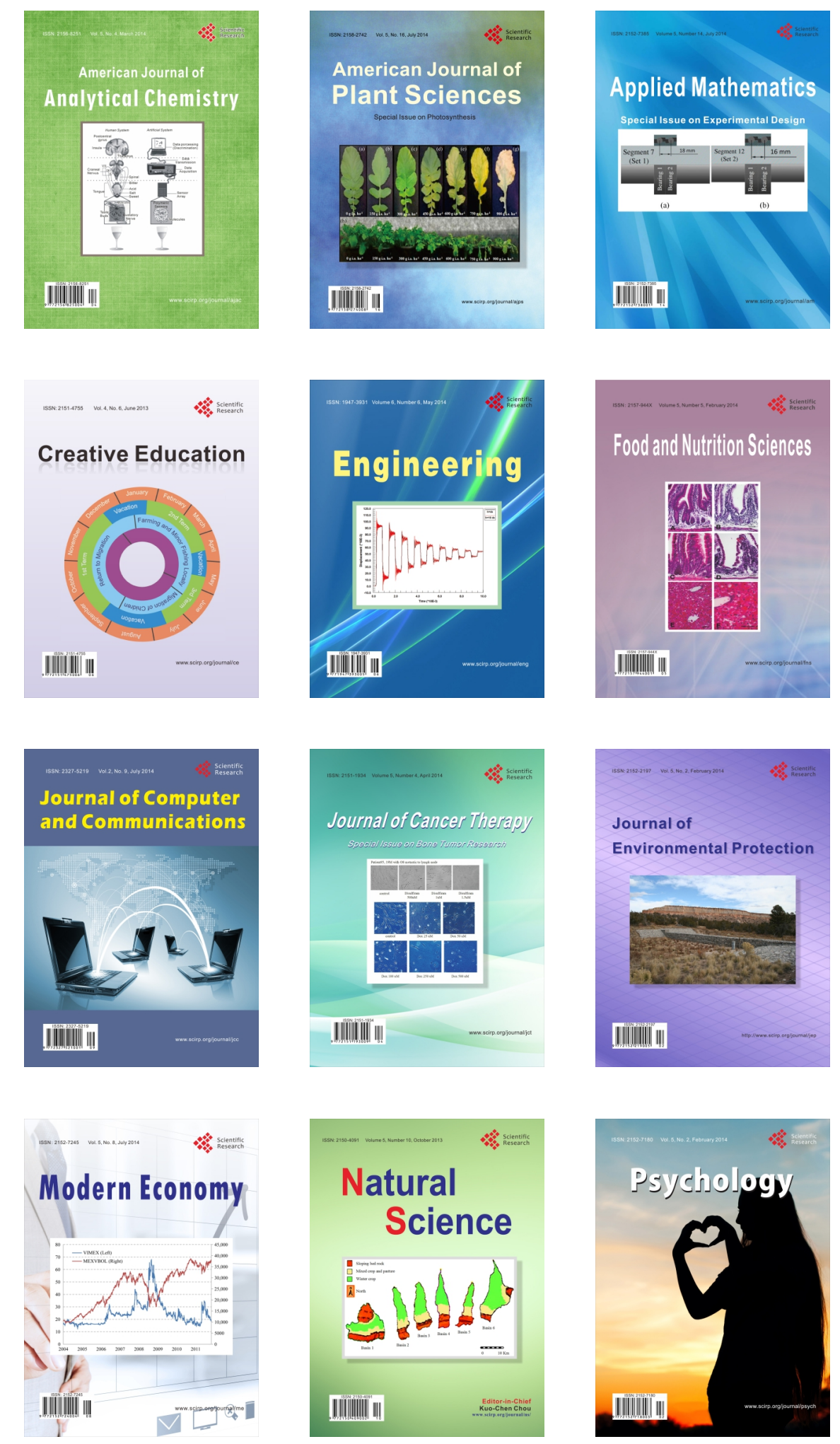